\title{
Mikro-struktury w przestrzeni miejskiej w aspekcie zrównoważonego rozwoju
}

\section{Micro-structures in urban spaces in the aspect of sustainable development}

Streszczenie

Ontogeneza jednostki ludzkiej nierozerwalnie związana jest z ruchem. Współcześnie, koncept nomadyzmu ulega transformaw presí rozwoju cywizacyjnego nabierajac szerszego znaczenia i wkraczając wobszary zwiazzane z szeroko pojmowaznaczenia i przyszłości tradycyinego myślenia i kształtowania struktur architektonicznych we współczesnych przestrzeaich miejskich. Artykut koncentruje sie na tymczasowych i mobilnych strukturach w kontekście urbanistycznych, materiatowych i konstrukcyinych rozwiazán. Biorac pod uwage nietypowe przestrzenie stacjonowania tymczasowych i mobilnych struktu 作 wiązania wymagają innowacyjnego podejścia projektowego XXI w.

Abstract

Ontogenesis of human being is constantly connected with the movement. Nowadays, the concept of nomadism is being ransformed in the process of forming of the human civilization, acquiring a wider meaning and infittrating the areas conneced with civilization movement, including digital space. Dynamic civilization changes are the basis for a discussion about meaning and future of traditional thinking of shaping the architectural structures in the contemporary public spaces. This paper focuses on temporary and mobile structures from the urban context to contemporary material and construction solutions. Considering the unusual places of stationing of temporary and mobile structures, such as degraded areas or inaccessible urban spaces, these structures require innovative and creative design solutions in 21st century.

Slowa kluczowe: architektura

\section{WSTEPP}

Zgodnie z Raportem Living Planet z 2016 r., tzw. Living Planet Index (LPI) zmniejszył się o około $58 \%$ w latach 1970-2012. Wskaźnik LPI zawiera dane dotyczace 3706 gatunków kregowców wystepujących na świecie. Równocześnie zużycie surowców, w tym wykorzystanie dwutlenku wegla, wody pitnej i ubytki lasów tropikalnych, zwiekszyło sie dramatycznie [1]. Można postawic istotne pytanie, czy istnieją środki i możliwości kontynuowania rozwoju przy jednoczesnym poszanowaniu środowiska naturalnego? Jedną z odpowiedzi mogą być tymczasowe i mobilne struktury, które są ściśle związane z koncepcją ruchu $w$ architekturze. W nomenklaturze architektonicznej pojawiają się liczne koncepcje związane z bezpośrednio z ruchem, m.in.: struktury mobilne, w tym przenosne, architektura elastyczna i kinetyczna oraz struktury przeksztalcalne i responsywne. Rozwiązania projektowe związane z ideą ruchu stanowią często kompilację nurtów i koncepcji wymienionych powyżej.

\section{INTRODUCTION}

According to Living Planet Report from 2016, Living Planet Index (LPI) have declined for about 58 per cent from 1970-2012. The global LPI contains data of 3706 vertebrate species from living population around the world. In contrary, human activities and accompany resources uses, such as carbon dioxide use, freshwater use or tropical forests loss have grown dramatically [1]. The main question is whether there are ivities while respecting the environment? One of the answers can be mobile architecture and temporary structures which are closely related to the concept of movement in architecture. In nomenclature of architecture there are a number of concepts relating directly to the movement, such as mobile architecture including portable structures, flexible and kinetic architecture, deployable and responsive structures. means and capabilies to continue development ac-

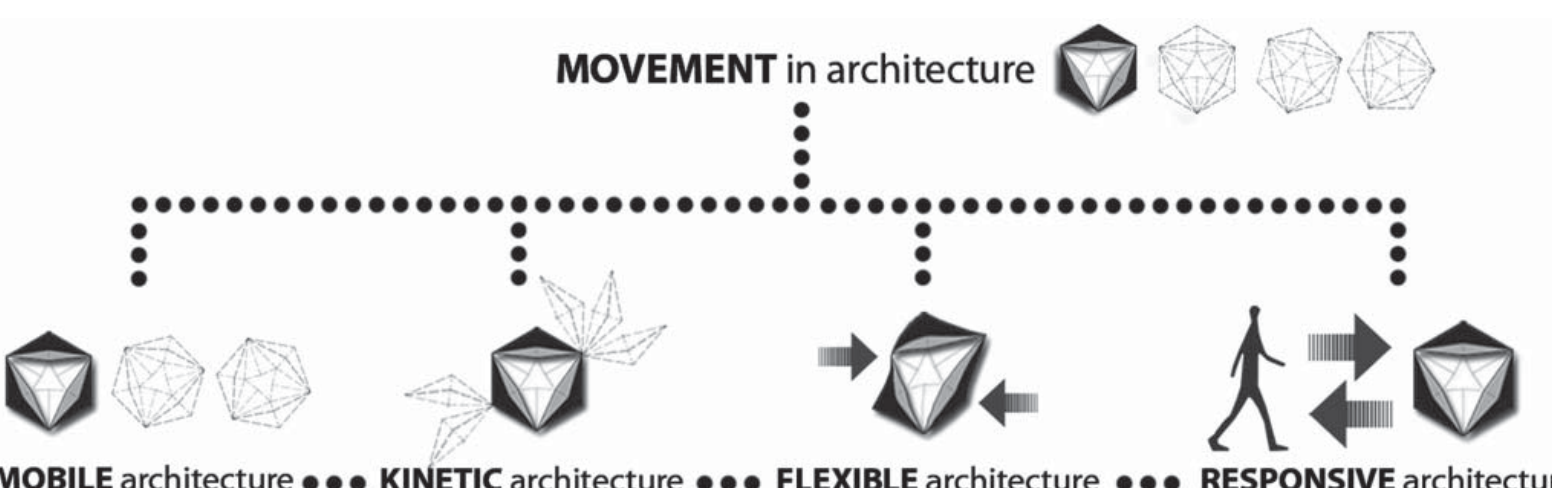

MOBIL

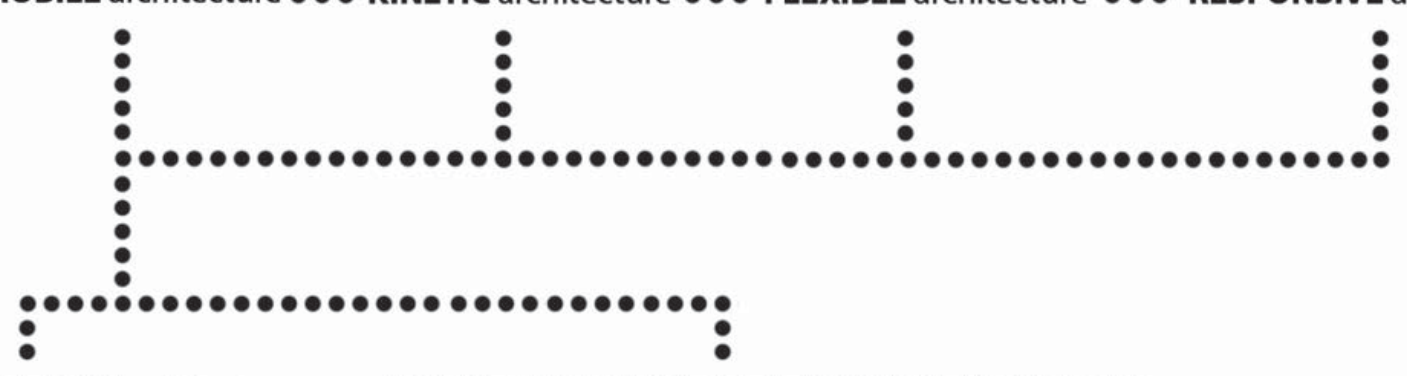

PORTABLE architecture MOBILE STRUCTURES STATIONING TEMPORARILY

II. 1. Schemat ruchu w architekturze $z$ uwzzlednieniem różnorodnych koncepcij struktur zwiazzanych z ruchem, autor: Anna Berbes

Artykuł dotyczy architektury mobilnej, w tym struktur A nych przestrzeniach miejskich.

\section{TRANSGRESJA ARCHITEKTURY}

Architektura mobilna i struktury stacjonujące tymczasowo wykraczają poza tradycyjnie rozumianą architekturę. Zgodnie z Triadą Witruwiusza istnieją trzy główne determinanty dotyczące rozwiązan architektonicznych, tj.: utilitas, venustas and firmitas [2]. Pojęcie firmitas można rozumiec jako "trwalosic", co może prowadzic do konkluzji, że struktury mobilne i tymczasowe nie sa sciśle związane z podstawową koncepcją architektury a z, tzw. "transgresją architektury". Ponadto, architektura mobiha i tymczasowa nie jest związana permanentnie $z$ gruntem i może stacjonowac w przestrzeniach zurbanizowanych, $\mathrm{t}$. nowoczesne i historyczne centra miast ralne.

\section{TRADYCYJNY KONCEPT NOMADYZMU}

Pochodzenie mobilnych i tymczasowych struktur jest związane $z$ koncepcja nomadyzmu. Obecnie funkcjonują społeczności nomadyczne wykorzystujące tradycyjn pry mieszkalne. Zgodnie z podziałem wprowa m przez prof. F. Grossa, nomadyzm może odnosić sie do dwóch typów:

- Nomadyzm typowy

Semi-nomadyzm periodyczny

Społeczność australijskich autochtonów - Aborygenów jest zwiazzana ściśle z koncepcja nomadyzmu, W tradycyjnym kształtowaniu struktur mieszkalnych, jako materiał bazowy, wykorzystywane były mocno splatane todygi typu mulga-scrub. Konstrukcja struktur mieszkalnych
Projects related to the idea of movement are often compilations of the concepts above. This paper is based on the mobile architecture such as portable or stationing temporarily mobile structures in contemporary urban areas.

TRANSGRESSION OF ARCHITECTURE TRANSGRSSION OF ARCHTCTURE tures are something more than the common undering of the arch the architecture. According to Vitruvius thad, there are three determinants of architecture, such as utilitas, venustas and firmitas [2]. The third one means 'solid", that shows the mobile and temporary structures are not closely related to the basic can called 'transgression of architecture'. Moreover, mobile architecture and temporary structures are not linked permanently to the ground and can allow to sim pact on the environment.

TRADITIONAL CONCEPT OF NOMADISM

The roots of mobile and temporary structures are connected with the concept of nomadism. Nowadays, there are several nomadic communities and their habitable structures that still exist around the world. According to prof. F. Gross, nomadism issue can be divided into two types [3]:

- Typical nomadism

- Periodic semi-nomadism. 


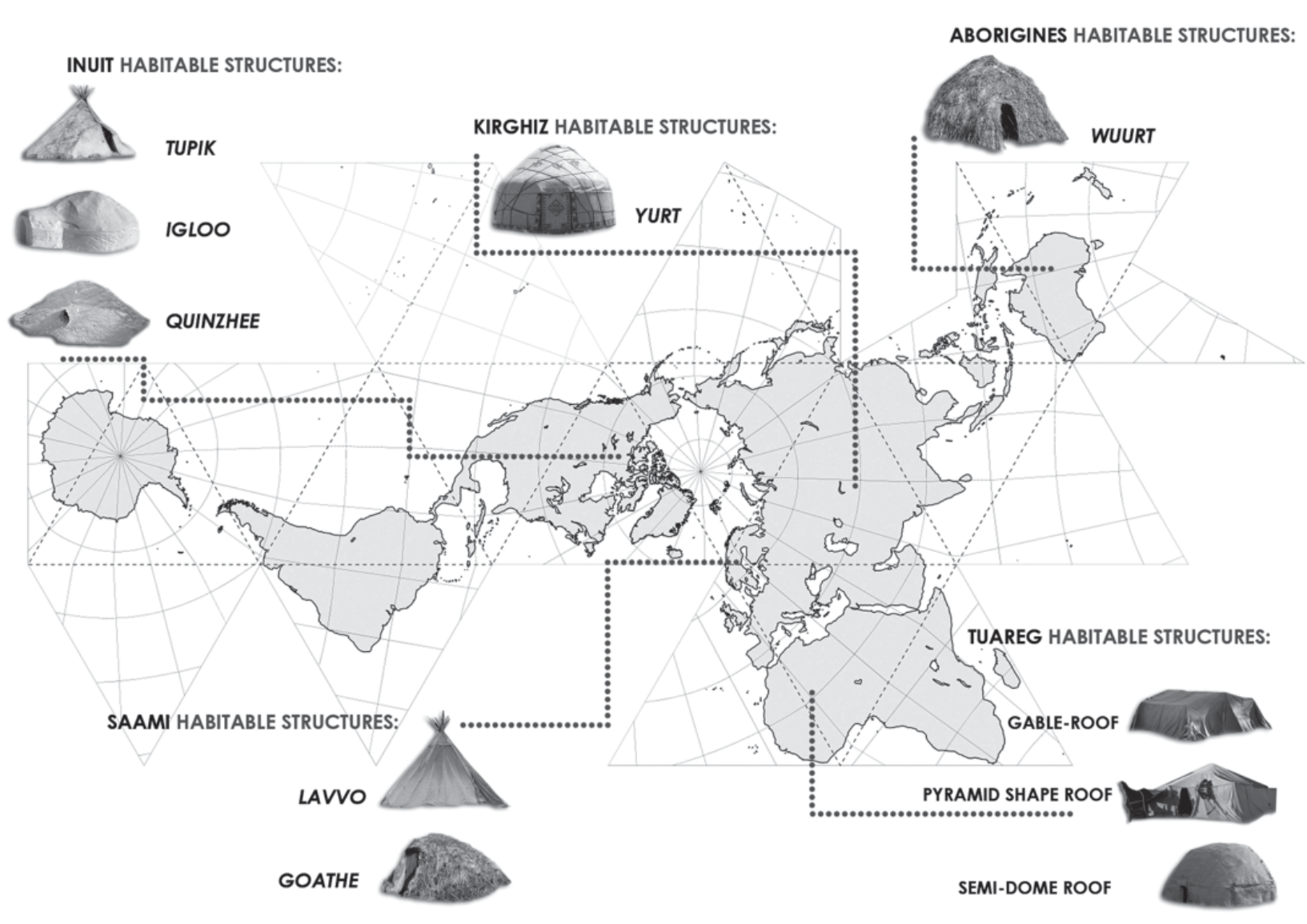

II. 2. Schemat typów nomadycznych struktur mieszkalnych wraz z ich lokalizacjami, autor: Anna
III. 2. Scheme of types of nomadic habitable structure and locations, illustration: Anna Berbesz

opierała się na planie koła, a poszczególne jednostki zlokalizowane były wokół głównego źródła ciepła - og niska otwartego [4]. Kolejnym przykładem nomadyzmu typowego są społeczności Tuaregów, nazywanych "błękitnymi ludźmi Sahary". Ludy nomadyczne Tuaregów dzielą się na dwie główne podgrupy: Tuaregowie z pótnocy, żyjący na obszarze Sahary (3\% populacji) i Tuaregowie południa, zamieszkujący tereny stepów Sahelu (97\% populacji) [5]. Struktury mieszkalne Tuaregów sa scisle powiazzane $z$ aspektami społecznymi (matriarchat). Konstrukcja struktur mieszkalnych zlożona jest z ramy szkieletowej z wykorzystaniom galęzi jako materialu plecionych liści palmowych. Stosowan sa trzy rodzajo ksztatu dachu: dach dwuspadowy, wuktzie piramidowym lub para-koputowym. Ekstemane rózice klimaty

clatya swoje odzwierw funkcjonowaniu człowieka - nomady, któn jest ściś potaczony z lokalnym ekosystemem. Granice pomie dzy poszczególnymi strefami sa powiazzane z migraciami ludów semi-nomadycznych, przemieszczajacych się $z$ własnymi strukturami mieszkalnymi. Jednym z przy kładów sa społeczności Inuitów stosujacych trzy rodzajjednostek mieszkalnych: tupik, igloo i quinzhee [7]. Pótnocna cześć kontynentu eu przez społeczności nomadyczne Saamów. Są oni autochtonami rejonów skandynawskich, zamieszkujacych
The community of Australian autochthons - Aborigines, are related to typical nomadism concept. In traditional way of creating settlements, their habitable structures were made of mulga scrubs. The construction of living structures was founded on a circula plan and located around main fireplace [4]. Another examples of typical nomadism is Tuareg community called 'The Blue People from Sahat'. Tuareg communities are mainly divided into two groups: Tuare from the north, living on the Sahara desert $(3 \%$ of population) and Tuareg from the south, living on Sahel steppes (97\% of population) [5]. Their habitable structures are strictly related to social aspects (matriarchy). The construction of houses are skeletontype framework made of branches and covered by animals skin fabric and plaited palm leaves. There are three main types of ceiling: gable roof, pyramid shape and semi-dome shape [6].

Extreme climatic differences reflected in the biodiversity of nature and also in human - nomad who is closely connected with the local ecosystem. Boundaies of ponnected with the local ecosystem. Boundar ies of particular zones are coincided with migration of For example, people and their habitable structures. tupik, igloo and quinzhee

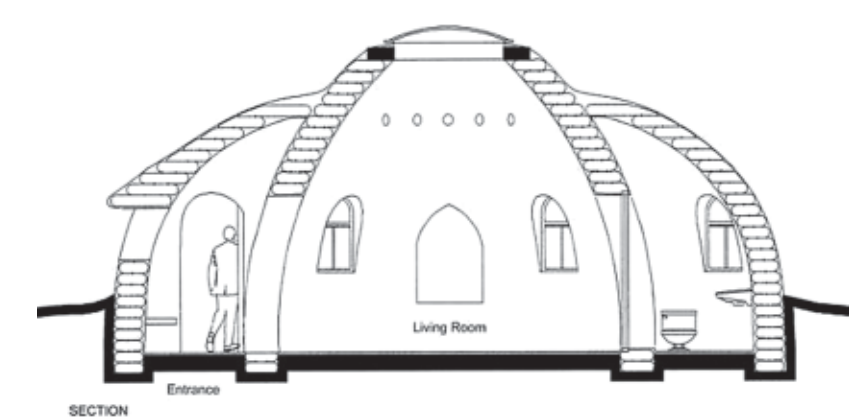

III. 3. Przekrój przez konstrukcje struktury Sandbag Shelter, źródto: step: 22.11.2017
III. 3. Section of Sandbag Shelter construction, source: $h$ htp: $/ /$ www.eart-
hbagbuilding.com/projects/sandbagshelters.htm, access: 22.11.2017

w dwóch głównych typach struktur mieszkalnych: goathe i lavvo. Pierwsza z nich jest struktura para-koputow składającą się z cegiet, drewna i torfu. Druga z nich, typu lavvo jest ksztattowana analogicznie do inuickich struktur typu tupik, czy indiańskich tipi i zbudowana jest z pali drewnianych w kształcie stożka z pokryciem ze skó zwierzęcych.

Zagadnienie nomadyzmu, poza swym degeneratywnym charakterem, pojawia się również obecnie i stanow swoiste continuum poruszania się i ksztaltowania osad ludzkich. Współcześnie, pojawiają się obiekty architektoniczne inspirowane nomadycznymi strukturami mieszkalnymi. Jednym z nich jest Kakslauttanen Igloo Village w Laponii, ktorej glowną inspirację stanowito $/ g l o o$ inuickich nomadów. Kolejnym przykładem jest budyne Parlamentu Saamów w Karasjok inspirowany struktura Lavvo nomadycznych autochtonow.

Wspołczesne architektoniczne rozwiązania są również przykładem kompilacji architektury wernakularne struktur nomadycznych. Jednym z przykladów jest Sandbag Shelter zaprojektowany przez Nader'a Khalit założyciela California Institute of Earth Art and Architecture. Koncepcja struktury jest proba wypełnienia zapotrzebowania na rozwiązania architektury mieszkaniowe jest glownie dedykowana uchodźcom oraz ofiarom wojen I klęsk zywiolowych. Konstrukcja jest ksztaltowana za pomoca workow ha piasek wypelnionych ziemia ków ulożony jest system z drutu petniquy role rozciagjaç i zapewniajacy odporność konstrukcii na trzesienia ziemi. Prototyp Sandbag Shelter otzymat nagrode Aga Khan Award w dziedzinie architektury w 2004 r. Wysoka Komisja Narodów Zjednoczonych do spraw Uchodźców (UNHCR) oraz Program Narodów Zjednoczonych doty( zacy Rozwoju (UNDP, ang United Nations Development Program) wykorzystywali te strukture do tworzenia tymczasowych schronień dla uchodźców z Iraku przybywajacych do Iranu w $1995 \mathrm{r}$. [8].

\section{MEGASTRUKTURY JAKO INSPIRACJE DLA ARCHITEK-} TURY MOBILNEJ

Poczatek XX w. w europejskiej sztuce i architekturze by kształtowany pod wpływem fascynacji technologią i re-
European continent is inhabited by nomadic people live in two types of habitable structures: goathe and lavvo. The first one is a semi-dome structure made of brick, timber and turf. On the other hand, lavvo is shaped similarly to Inuit's tupik and Indian's tipi and it is made of thin timber piles shaped like a cone covered by animals skin.

Nomadism, despite it degenerative character, is continuing in the present and is an example of a specific continuum of movement and settlement of human beings. Nowadays, there are architectural building which were inspired by nomadic habitable struc tures. One of them is Kakslauttanen Igloo Village in Lapland, which main inspiration was $/ g / o o$ of Inuit nomads. Another example is Saami Parliament in Karasjok, which main inspiration was Lavvo structure of Saami nomads.

polutions are also examples of the combination between vernacular archacture is the Sandbag Shelter designed by Nader Khalili who was a founder of the California Institute of Earth Art and Architecture. This concept is an attempt to fulfill the global need for housing architecture and is mainly dedicated to the refugees or victims of was and natural disasters. The construction is based on the sandbags filling with earth and laying in a circular plan. Between the layers the barbed wires are laid to play role of tensile elements and provide earthquake resistance. Sandbag Shelter Prototype was the winner of Aga Khan Award in Architecture in 2004. United Nations High Commission for Refugees (UNHCR) and the United Comions Development Program (UNDP) the Iraq refugees coming to Iran in 1995 [8].

\section{MEGASTRUCTURES AS AN INSPIRATION FOR MO-}

\section{BILE ARCHITECTURE}

The beginning of the $20^{\text {th }}$ century in European art an architecture was influenced by technology fascina tion and industrial revolution. Furthermore, a huge impact on architecture had also modernist international style. Le Corbusier and Pierre Jeanneret formulated five principles of new architecture in 1926 In the context of mobile and temporary structures, the most important principle was free planning of buiding. That structural solution have provided freedom in creating architectural objects [9].

As a result of traumatic experiences of First and Second World Wars, the direction of architectural activities has changed. In the second half of the 20th century, a number of mega-structural utopian visions were created. The concept of movement, mobility and adaptability of the utopian cities had significan 
wolucją przemysłową. Ponadto, szczególny wpływ na architek ure mial międzynarodowy styl modernistyczny w 1926 r. W kontekscie struktur mobilnych i tymczasowych, najbardziej istotnym założeniem było swobodne planowanie budynku. Rozwiązania strukturalne zapewniały swobodę w kreowaniu obiektów architektonicznych [9].

W rezultacie traumatycznych doświadczeń I i II Wojny Światowej zmienit się kierunek ksztaltowania rozwiąza architektonicznych. W drugiej połowie XX w. powsta szereg wizji megastruktur. Koncepcja ruchu, mobilności, adaptacji miast utopijnych miała szczególny wpływ na wizje architektoniczne. Architektura była pojmowana jako rama lub konstrukcja szkieletowa dla różnorodnych działan przestrzennych.

Po ost Jawla sie grupa Groupe d'Eudes d'Architecture Mobile twórca utopijnych rozwiazań odbiegajacych znaczni od tradycyinie poimowanej architektury. Podczas ostatniego kongresu CIAM w Dubrowniku, Y. Friedmann przedstawi swój Manifesto d'Architecture który rómnież zostat przesłany do Le Corbusiera i Richarda Buckminstera Fullera których uzyskał pozytywne odpowiedzi i prowadzit da, od korespondencje. Jednym z głównych założeń Y. Friedmorespondencję. Jednym z głownych załozeń Y. Friedzastosowaniu minimalnej struktury. Urbanistyka oznaczała dla niego wolność $w$ kreowaniu przestrzeni do życia przez samych mieszkańców w stabilnej i sztywnej infrastrukturze. Członkowie grupy GEAM dostrzegali możliwość permanentnych zmian na każdym poziomie ludzkiego życia - w kontekście biologicznym, socjologicznym, psychologicznym i technologicznym [10]. Tworzenie zewnętrzne] megastrukturalnej ramy dla mobilnych, przenośnych jednostek, stanowilo główną ideę konceptu Y. Friedmanna, co miało odzwierciedlenie $w$ wielu projektach, tj. Ville Spatiale, czy struktur miast-mostów.

Symultanicznie, w Anglii idee megastruktur, oparte na koncepcie ruchu $w$ architekturze, były kontynuowane w latach 60. XX w. w wielu futurystycznych i utopijnych projektach tworzonych przez nowe architektoniczne zespoły, m.in. grupe Archigram. Projekty, które w pełn implementowały koncept ruchu, dynamiki i zmienności tkanki miejskiej to, m.in.: Walking City Rona Herrona Plug-in City Petera Cooka oraz Computer City Dennis Cramptona [11]. Ze współczesnego punktu widzenia, kriepeje Archigramu mogly byc wizualnymi zapowiesieci internetowych Obecrie, wizje samowystarczajacych obiektów pojawiaja sie przy tworzeniu domów jaych obicktón pojaw waja się przy tworzeniu domón funkcjonować niezależnie bez połączenia do zewnętrznych przyłączy instalacyjnych.

W Japonii, $w$ pierwszej połowie lat 60 . została założona grupa Metabolistów której aktywność poz znaczacy wpływ na myślenie projektowe wielu generacji architektów. Grupa powstała jako konsekwencja organizacji World Design Conference w 1960 r. w Tokio. Grupa zrzeszała nastepujących członków: Kishō Kurokawa, Kenzõ Tange, Kiyonari Kikutake, Noboru Kawazoe, Masato Otaka and Fumihiko Maki. Idee oraz influence on architectural conceptions. Architecture was supposed to be a framework or a skeleton for variable actions in space.

After the last CIAM congress in Dubrovnik in 1956, in the area of architectural visions Groupe d'Etudes d'Architecture Mobile (GEAM) founded by Yon Cried alor of the ungian solutions flistant beyond the traditional understanding of architecture. During the last CIAM congress, he introduced his Manifesto d'Architecture, which also sent to Le Corbusier an R. Buckminster Fuller, from whom he had got positive reply and ran further correspondence. One of the main purpose of Y. Friedmann was to obtain the maximum flexibility within the minimum structure. Urbanism meant for him a freedom in shaping the living space by the inhabitants in the stable and rigid infrastructure. The members of GEAM had seen the possibility of permanent changes in every level of human's live - in biological, sociological, psychologica and technologicalcont [10]. Creation of externat in for $Y$. Fiedmann what is included in many projects, such as Ville Spatiale or city-bridges structures.

Simultaneously, in England the ideas of mega-structures based on the concept of movement in architecture were continued in the 60 . in many futuristic an utopian projects creating by new architectural teams like Archigram. The projects which fully implemented the concept of movement, dynamic and variability of the city are, i.a. Walking City by Ron Herron, Plugin City by Peter Cook or Computer City by Dennis Crampton who were members of Archigram tean 11. From present point of view, Archigram co ram concepts an be a visual announcement of contemporary cyerspace and virtual networks. Currently, the vision of self-sufficient objects are implemented to autonomous houses or off-grid structures which can function independently without access to external installations.

In Japan, in the first half of 60. the Metabolism group was formed, which activity left the significant traces in design thinking of successive generations of architects. The group was created in consequence of organizing the World Design Conference in 1960 in Tokyo. The members of Metabolists were: Kisho Kurokawa, Kenzõ Tange, Kiyonari Kikutake Noboru ka Kawaze, Masuto Otara and cially presented in the Manifesto in 1960. Kishô Kuroan an in claimed that society should be understood as an integral part of the whole nature, including the world of plants and animals and remaining in opposition to common belief that modernization is a return założenia Metabolistów zostały oficjalnie zaprezentowane w Manifeście w $1960 \mathrm{r}$. Kishoo Kurokawa twierdzit, że spoleczenstwo powinno byc rozumiane jako integraln część srodowiska naturalnego, włączając świat rośli i zwierząt, pozostając w opozycjji do popularnego twie dzenia, ze nowoczesnosc prowadzi do konfliktu pomie dzy technologia a naturą. W swoich futurystycznyc wizjach i realizacjach projektowali $w$ trzech przestrzeniach naszej planety: w środowisku lądowym, wodnym oraz w powietrzu. Szczególnie w środowisku lądowym został zaprojektowany szereg koncepcji bazujących $\mathrm{n}$ przenośnych oraz kapsułowych jednostkach. Rozwiazania kapsułowe stanowily rozpoznawalny i istotny element projektow Metablizmu. Kenji Ekuan kontynuowa prowadzenie badań dotyczących jednostek mobilnych ise House (1964), dom, który mógt być rozbug tonony w kierunu wertykalnym i horyzontan Hermit Crab Capsule Lodge (1969) był mobilna kapsul $z$ możliwością lokalizacii w trudnodostenych miejsach w tym na szczycie gór i wzniesień, przemieszczana za pomocą zewnętrznego środka transportu [12].

Koncepcia ruchu w architekturze XX w. pojawiała sie stopniowo w zależności od historycznego i technolo gicznego kontekstu. Z drugiej strony, dynamizm, ruc i mobilność były bardziej swobodnie przenoszone do przestrzeni sztuki, ze wzgledu na nieograniczona możliwość ekspresji. W realizacjach architektonicznych rozwiązania oparte na motywie ruchu były implementowane w wolniejszym tempie, ze względu na ograniczenia technologiczne. Równolegle, powstawały liczne koncepcje utopijnych wizji bazujących na aspekcie mobilności. W rezultacie fascynacji wizjami niograniczonymi rozwojem technologicznym zaczęły powstawac projekty złozonych miast - Megastruktur zapewniających przestrzen dla nowoczesnego człowieka.

ARCHITEKTURA MOBILNA W KONTEKŚCIE ADDY TYWNOŚCI W PRZESTRZENIACH MIEJSKICH

Mobilne i tymczasowe struktury we współczesnych przestrzeniach miejskich miast XXI w. mogą stanowić podstawę dyskusji dotyczącej addytywności w kontekści urbanistycznym. Kolejną determinantą może być rodza srodowiska, w. korym dane struktury mogą byc lokalzowane (środowisko lądowe, wodne, z uwzględnieniem nabrzezy sródlądowych i przestrzenie ponad gruntem). Jedny z przllow w addythosci w przestzen struktura typu walk-in o pow. użytkowe rzedu $9 m^{2}$. Re alizacja stanowita kooperacje pomiedzy Stefanem Eberstadtem i Thomasem Beckiem. Gtówna idea projektu było stworzenie dodatkowej przestrzeni dla istniejacych budynków mieszkalnych. Obiekt jest prostopadłościenna strukturą w konstrukcji stalowej z pokryciem ze sklejk drewnianej z żyica z zastosowaniem pleksiglasu jak przeszkleń okiennych. Struktura została podłączona do fasady lub dachu budynków istniejących za pomoca cięgien stalowych. Struktura o wymiarach $250 \times 360 \times 250 \mathrm{~cm}$ była prezentowana po raz pierwszy w Kolonii w 2005 podczas Międzynarodowego sympozjum architektonicznego Plan05 (Forum of Contemporary Architecture) [13] to the conflict between technology and nature. With the Metabolists design in three spaces of our planet: terrestrial, water and air. On the terrestrial environment, they created a number of projects based on the portable and variable capsule units. Capsules were an impotant and recognizable element of Mecapsures in a number of projects, House (1964) which cou (196) which could be exHermit Crab Capsule Lodge (1909, proj Kenj EkKar ( was a mobile capsule which can be placed even on 作 means of transport [12].

the concept of movement in $20^{\text {th }}$ century architecture emerged gradually depending on the historica and technological context. On the other hand, $d y$ namism, movement and mobility were much more freely presented in art, due to unrestricted ability of rechitectural realizations the solutions based on the movement concept were implemented in slower way, because of technological limits. In contrary, there were many conceptual utopian vi sions based on the mobility aspect. As a result of fascination with the vi development the first conceptual projects of complex cities - Megastructures which were supposed provide space for modern human were created.

MOBILE ARCHITECTURE IN CONTEXT OF ADDITIVITY IN URBAN SPACES

Mobile and temporary structures in contemporary urban areas of $21^{\text {st }}$ century cities, can be discussed in context of additivity in urban space. Another determinant can be the type of environment in which these structures are located, such as aboveground errestrial and aquatic areas including waterfronts. One of the examples of additivity in urban areas in aboveground environment is a Rucksack House, which is a $9 \mathrm{~m}^{2}$ walk-in structure. It was cooperation between Stefan Eberstadt and Thomas Beck. The main idea of this project was creating an additiona room for existing residential buildings. It is a welded steel cube covered by plywood with absorbed resin and plexiglass sheets use as a windows. The construction is based on the steel cables which are an chored to the façade or roofs of existing buildings The structure measures $250 \times 360 \times 250 \mathrm{~cm}$ and was presented for the first time in Cologne in 2005 during the International architectural symposium Plan05 (Forum of Contemporary Architecture) [13]

One of the most important issue in urban spaces is the using of flat roofs. Nowadays, there are more and more examples of objects which can partly solve 

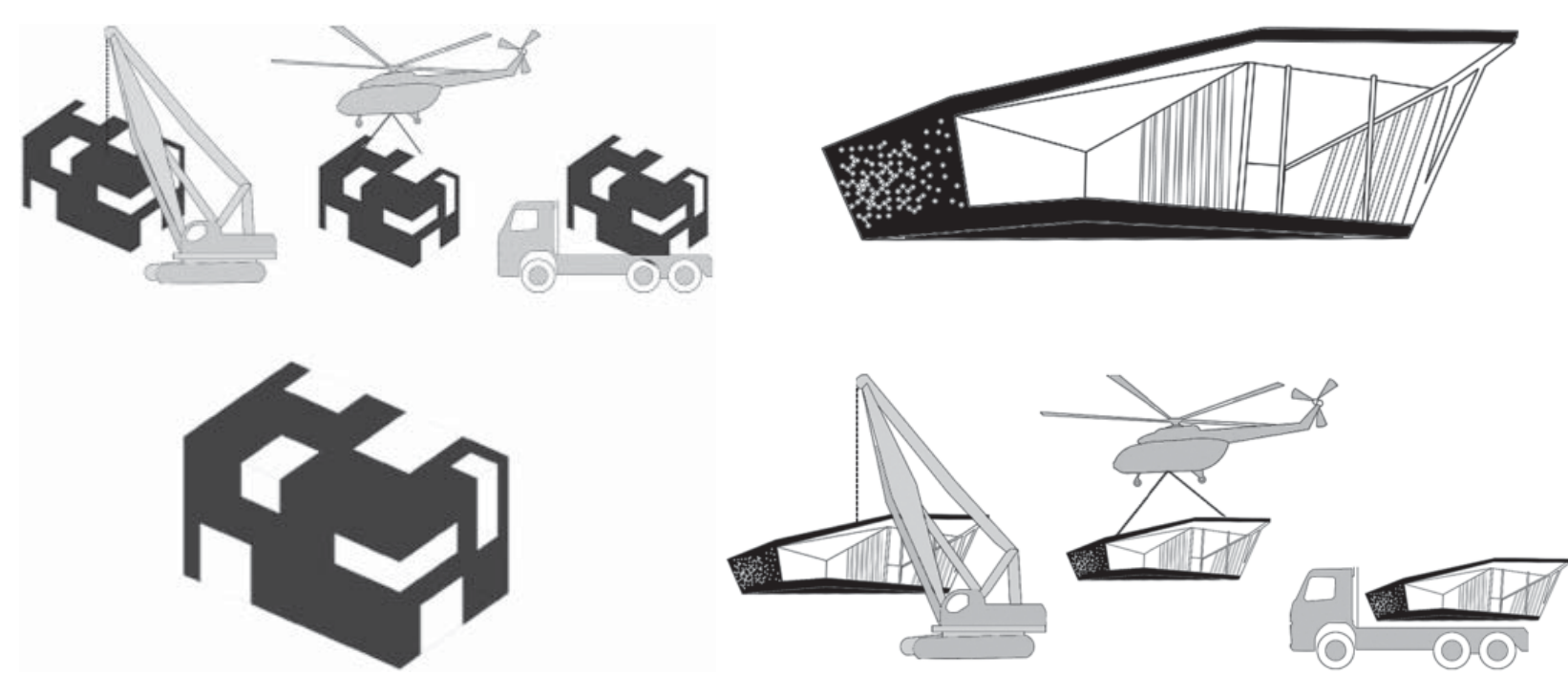

III. 4. Koncepcia Rucksack House, autor: Anna Berbesz / Conception of a Rucksack House, illustration: Anna Berbesz
II. 5. Schemat struktury The Cube i rodzajóow transportu, autor: Anna Berbesz / Scheme of The Cube structure and means of transport, illustra-
tion.

Jednym z najważniejszych elementów przestrzeni zurbaWowanych jest uzycie whome stropodachów plaskich. Współcześnie pojawia się coraz więcej przykładów obiektow, które mogą w częsci stanowic rozwiązanie tego problemu. Projekt The Cube powstat w kooperacji pomiędzy Park Associati i grupy Electrolux. Korzenie idei projektu sięgaja utopijnego, radykalnego projektu Ettore'a Sottsassa z 1972 r. pod nazwą: "The planet as festiwal". Główn idea The Cube było stworzenie tymczasowo stacjonujacych struktur umieszczanych na dachach budynków istniejących. Struktura była zlokalizowana przez sześć miesięcy w róznych miastach: Mediolanie, Belgii, Sztokholmie Londynie. Mobilna restauracja o pow. uzytkowej $140 \mathrm{~m}^{2}$ dostepna dla gości, strefe kuchenna z przestrzeniami maozynowyi, toalety ogólnodostepne i tarasem o pow $50 \mathrm{~m}^{2}$. We wnetrzu zostat zaprojektowany podtużny stó dla gości z możliwościa jego podnoszenia w kierunku wertykalnym w celu maksymalizacii otwartej przestrzeni. Sciany wewnetrzne zostały pokryte białym materiatem typu Corian i lakierowanymi płytami meblowymi. Podtoga została pokryta deskami drewnianymi i dywanem. Pokrycie sufitu stanowia ażurowe panele o właściwościach akustycznych. Złożenie struktury w nowej lokalizacii zajmuje dziewięć dni i wymaga zaangażowania osiemnastu ludzi. Gówną konstrukcję obiektu stanowią prefabrykowane elementy drewniane pokryte panelami aluminiowymi wycinanymi laserowo [14]

Kolejnym przykładem wykorzystania płaskich stropodachów jest instalacja Your Rainbow Panorama autorstwa Olafura Eliassona. Struktura składa się z przestrzeni pieszej długości $150 \mathrm{~m}$ na planie okręgu o średnicy $3 \mathrm{~m}$ $w$ której przegrody zewnętrzne wykonane zostały ze szkła w kolorystyce spektrum swiatla widzialnego. In stalacja, zlokalizowana na stropodachu Muzeum Sztuk Współczesnej ARoS w Aarhus w Danii, stanowi dialog pomiędzy architekturą a sztuką [15]. that problem. The Cube is a project made in cooperation between Park Associati and Electrolux. The roots of the idea of this structure is an utopian and radical project by Ettore Sottsass from 1972 called 'The planet as festival'. The main idea of The Cube is to build a temporarily stationing cabin and place it on the top of existing buildings. This structure as located for six months in different cities: $\mathrm{Mi}$ was mobile restaurant was divided into an open dining avea avaluble for guests, kichen space with tora terior Io ter vertically moved to provide maximum open space. Interior walls were covered with white Corian material and lacquered furniture board. The floor was covered with wooden boards and carpet. Cladding of the ceilings is a wooden acoustic openwork. Assembly of the structure in new location takes nine days and requires commitment of eighteen people. The main construction of the object are prefabrient

Another example of using flat roofs is Your Rainbow Panorama by an artist Olafur Eliasson. This structure consist of circular walkway of $150 \mathrm{~m}$ long and $3 \mathrm{~m}$ wide which walls are made in glass in all colours of the light spectrum. It is a dialog between architecture and art. This installation is located on the top of ARoS Aarhus Kunstmuseum in Denmark [15].

One of the examples of terrestrial environment is BMV Guggenheim Lab by Japanese architects Atelier Bow-Wow. The project is the cooperation between Salomon R. Guggenheim Foundation and

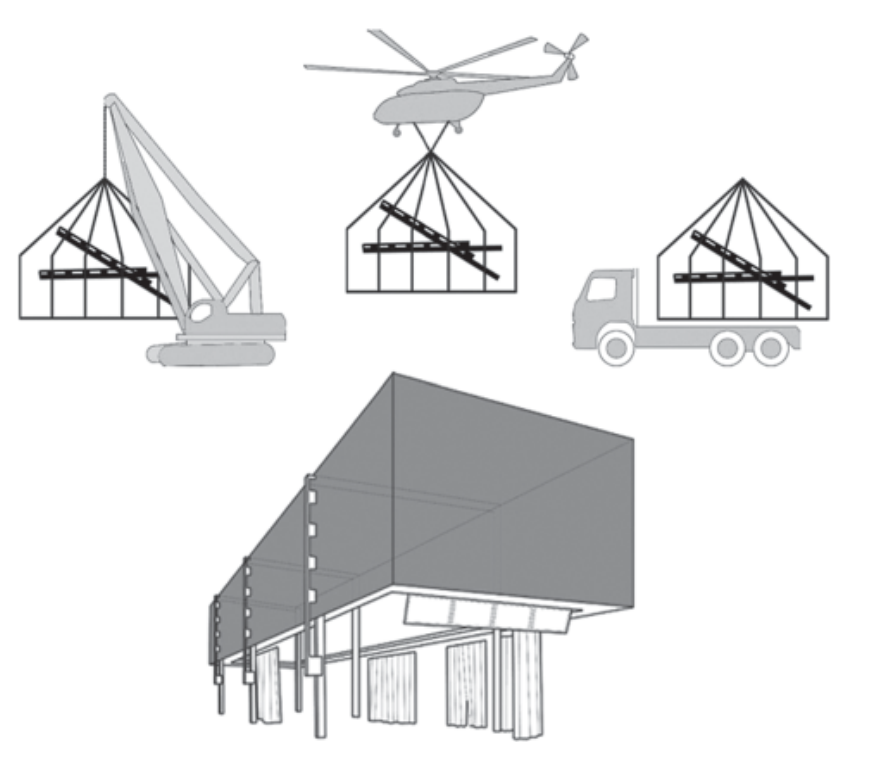

Jednym z przykładów stacjonowania struktur mobilnych w środowisku lądowym jest BMV Guggenheim Lab autorstwa japonskiego biura projektowego Atelier BowWow. Projekt stanowi kooperację pomiędzy Fundacja Salomona Guggenheima i grupą BNWV. Struktura została przenoszona do różnorodnych miast, ti.: Nowy Jork, Berlin czy Mumbaj. W aspekcie wizualnym obiekt został podzielony na dwie częsci - otwartą, adaptowalną strefę doln posadowioną na gruncie i zlokalizowaną wyżej strefę techniczną przeznaczoną na instalacje elektryczne, elektroniczne oraz oswietlenie. Strefa dolna została przeznaczona na wystawy, warsztaty oraz dyskusje dedykowane lokalnym spolecznościom w celu podjęcia tematow związanych 2 przestrzenią miejską. Konstrukcje stanowi prostopadłoscienna rama stalowa pokryta siatką mesh w górnej częsci. Lekka konstrukcja szkieletowa zostala zaprojektowan w celu ulatwienia przenoszenia i zansportu.

wa W Bombaju i powstala pray wspolpracy lokalnego biur pre linie i czesie staco jaycych wowy Jorku i Berkiej mandapy. Idea miejskego laboratorium" nie jest jedynie stworzenie struktury wypetniajacej gesta tkanke urbanisycza ale przeprowatenie solecznego ekserýn

People's Architecture Office w Chinach jest kolejnym przykładem architektuy mobinej w środowisku ladowym. Wieża mieszkalna est zaprojektowana w stalowej konstrukcii szkieletowej. Przestrzenie pomiedzy elementami konstrukcyjnmi moga zostać wypełnione jednostkami mieszkalnymi $z$ możliwościa ich przemieszczania. Moduły mieszkalne zostaty zaprojektowane z paneli wielowarstwowych przy zastosowaniu systemu PPS (ang. Plugin Panel System) składającego sie $z$ warstwy izolacyinej, przyłaczy insta lacyjnych i zewnetrznej okładziny [17], Kolejnym przykładem jest lekka instalacja przestrzenna zlokalizowana
6. Schemat struktury BMW Guggenheim Lab i środki 11.6. 6. stru, autor: Anna Berbes transportu, autor: Anna Berbesz
III. 6. S Sheme of The BMW Guggenheim Lah structure and
ans of transport, illustration: Anna Berbesz

MMW group. It is a portable structure located in difIn visual aspect the object was divided into two parts - an open adaptable lower part in the ground level and the upper part covered technical and electronic installation and lightning. The structure comprises a black steel box covered by the mesh-clad in the upper part. This lightweight framework is de werks and talks about city.

The second structure located in Mumbai was established with a local office SDM Architects. This object was visualy different from the structure stationing Wre visually different from the structure stationing Wew York and Berlin and was inspired by Indian mandapa. The idea of the Lab is to make a structure that will not only play an architecture role in density local inhabitants [16]

The Plugin Tower by People's Architecture Office in Thina is another example of mobile architecture in Crrestrial area. The tower is comprised of a steet . The empty spaces can be plugin by The Modules are made of Plugin Panet System that in-

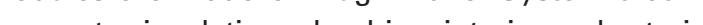
cold

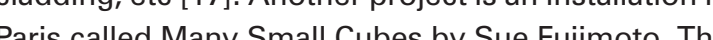
Pais called Many Small Cubes by Sue Fujimoto. The Pructure is intended to represent nomadic house The parly an architecture and parly a sculpture. The last context of mobile architecture are waterronts. One of the examples is Urban Rigger - a project that provide low-cost housing for students in hagen harbour. The solution was designed by BIG and is made of shipping containers located on 
w Paryżu o nazwie Many Small Cubes autorstwa Sue Fujimoto. Struktura, w załozeniu, ma pełnić rolę metaforycznego domu nomady i stanowi przykład dialogu między rzeźbą przestrzenną a architekturą tymczasowa. Ostatni kontekst stacjonowania architektury mobilne stanowią nabrzeża wód śródlądowych. Jednym z przykładów jest projekt Urban Rigger - założenie złożon jest z niskobudżetowych jednostek domów studenckich w kopenhaskim porcie. Rozwiązanie zaprojektowan przez grupę projektową BIG składa się z kontenerów dalekomorskich posadowionych na pływającej platformie Płaskie dachu kontenerów przeznaczone zostały na taras wienia paneli solarnych oraz przestrzenie zielone [18].

\section{PODSUMOWANIE}

Jednym z najważniejszych pozytywnych aspektów kształtowania struktur mobilnych itymczasowych jest możliwość przemieszczania obiektów wraz z ewentualną implementacja autonomicznego napędu. Ponadto, tego typu struktury mogą być lokalizowane w przestrzeniach zurbanizowanych i niezurbanizowanych właczajac reprezentatywn centra miast oraz $w$ strefach ekstremalnych lub trudnych warunków środowiska naturalnego w których posudnych nie tradycyjnych form architektonicznych jest utrudnione. Struktury mobilne realizuja ideę neo-nomady - człowiek ruchu. Pod względem założeń zrównoważonego rozwoju ze wzgledu na punktowe połączenie z gruntem, nastep uje redukcja wpływu obiektu na otaczające środowisko naturalne. Jedną z najważniejszych zalet jest cykliczna zmiana miejsca stacjonowania co zapewnia dynamiczną zmiane przestrzeni urbanistycznej w czasie rzeczywistym. Pojawia się mozliwosc ksztaltowania struktur, ktore mogą byc łatwo transportowane do stref dotkniętych skutkami klęs zywiołowych oraz konfliktow zbrojnych.

Głównym zagrożeniem kształtowania mobilnych i tymczasowych struktur jest stacjonowanie w przypadkowych lokalizacjach, co może prowadzic do dysharmon przestrzeni zurbanizowanej, głównie w zwartych centrach miast i nabrzeżach śródlądowych. Takie podejści wymaga specyficznych regulacji prawnych i rozwiązan odpowiednich dla struktur mobilnych i tymczasowych Wspołcześnie, do przewozenia tego typu struktu nie zbędne jest zastosowanie wielkoskalowych środków transportu i ciężkiego sprzętu, co prowadzi do zwiększenia kosztow. Co więcej, struktury mobilne stacjonumediów (instalacii sanitarnych i ecentro listh) co nie zawsze jest moiliwe, szczególnie w przestrzeniach niezurbanizowanych. Natomiast w celu zastosowania rozwiazań autonomicznych i typu off-grid, niezbedna jest wimen autonomicznych i typu off-grid, niezbedna jest implementacia

jest ale kształtowanie mobilnych i tymczasowych struktur jest alternatywną drogą projektowania obiektów, a dzięk cja procesu projektowania architektonicznego.

PRZYPISY

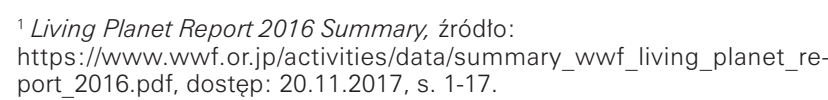

floating platform. The flat roofs of the top containers erent functions: a terrace, solar panels an green area [18]

\section{SUMMARY}

One of the most important positive aspect in creating mobile and temporary structures is the ability to move objects or possibility to implement an autonomous drive inside. Moreover, these structures can be located in urbanized or non-urbanized areas including representative city centres or extremely difficult to stationing environment conditions where applying of traditional forms of construction is impossible. Furthermore, the idea of a modern neo-nomad - a man in motion is possible to realize. Because of the lack of permanent connection to the ground, the reduction of negative impact of development on the environment occurs. There is also a possibility to create architectural objects based on the sustainable development. An important advantage is a cyclicalchange of stationing loction that lead to shape urban areas through dynamic of designing structurs in reat ine. There is an opportuity to build stuctures that con easily be transported to places affected by natural disasters or war conflicts.

The main threat in creating mobile and temporary structures is a random location, which can lead to disorder in urban spaces especially in compact city centres or inland waterfronts. This assumption requires specific law regulations and optimization relative to creation of mobile and temporary objects. Nowadays, the use of large-size means of transport (cranes, trucks) and heavy equipment is required. causes a number of additional costs. What is more, stationing of mobile and temporary structures re quires the connection with existing media (plumb-

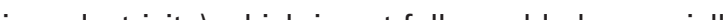
in non-urbanized ares In the case of using auromous and off-gas. In the case of using autonovide specilizedinstructures, it is necessary to provide specialized installations within the objects. Presently, creating of mobile and temporary structures is an alternative way for designing objects. As a result of technical development, permanent transformation of architectural solution is possible.

\section{REFERENCES}

'Living Planet Report 2016 Summary, source:
https://www.wwf.or.jplactivities/data/summary report_2016. pdf, ar.jpess: 20.11.2017, 1-17. Kumaniecki, Prószyński i i S., 1999 .
3 Gross F., Koczownictwo. Studja nad nomadyzmem i nad wpty-

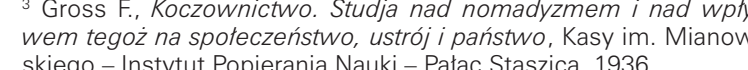
${ }^{4}$ Beben W. Aborygeni, piervsi nomadzi. Lycie i Kultura, Wydawn ctwo Uniwersytetu Gdańskiego, Gdańsk 20 . ${ }^{5}$ Rybiński A., Tuaregowiez Sahary. Tradycyina kultura Tuaregón Kel
Ahaggar rna przetomie XIX i XX W., Wydawnictwo Akademickie Dia-
Witruwiusz, OA Architekturze ksiag dziessę̨c, tlumaczenie: Kazimierz Kumanie

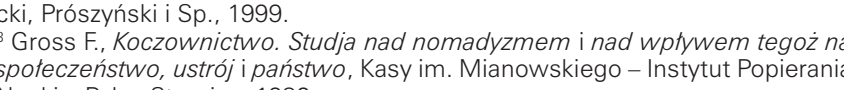
Nauki - Patac Stassica, 1936

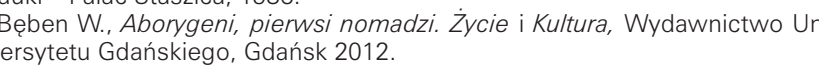

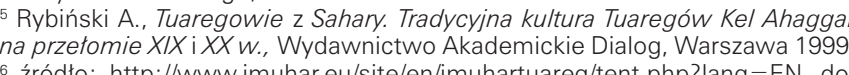
na prze/omie $X X X X$ W. Whydawnictwo Akademickie Dialog, Warszawa 1999
stęp: 20.06 .2019 Liródto e: http:
stẹp: 20.06.2019

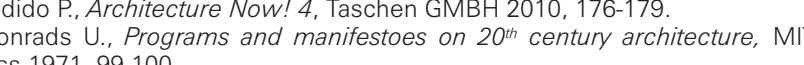
10 Busbea L., The Urban Utopia in France, 1960-1970, Massachusetts Institu of Technology, 2007 .
11 Jencks CH., Kropf K., Teorie i manifesty architektury wspótczesnej, Grupa
Szztuka Architektury. Warszawa 2013 s.258 Sztuka Architektury, Warszawa 2013, s. 258.
${ }^{2}$ Koolhaas R Obrist H. Project Japan Metabolism Talks. Taschen 2011. ${ }_{12}^{2}$ Koolhaas R., Obrist H.U., Project Japan. Metabolism Talks..., Taschen 2011.
13 Jodido P., Architecture Now! 4, Taschen GMBH 2010, 82-87. 14 żródto: hittp://Www.parkassociati.com/EN/Projects/2011/the_cube_by_elec

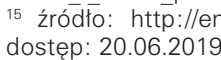

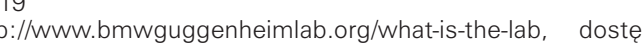
ziródto:

Zlodit: https://Www.treehugger.com/modular-design/modular-plugin-to

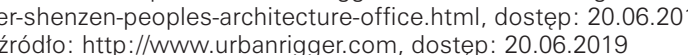

LITERATURA

11] Bęben W. Aborygeni, pierwsi nomadzi. Życie i Kultura, Wydawnictwo UniWersytetu Gdańskiego, Gdańsk 2012 . lute of Technology, 2007. Press 1971, 99-100

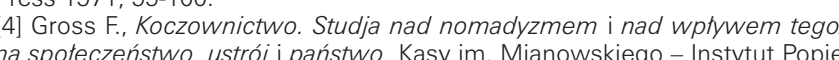
na spoteczeństwo, ustrój i pańśstwo.
rania Nauki - Patac Staszica, 1936.

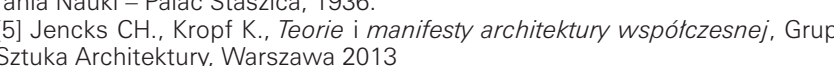
6) Jodido P., Architecture Now! 4, Taschen GMBH 2010
17] Koolhaas R., Obrist H.U., Proiect Japan. Metabolism Tat

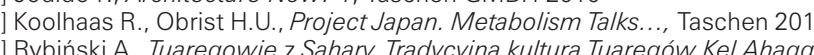

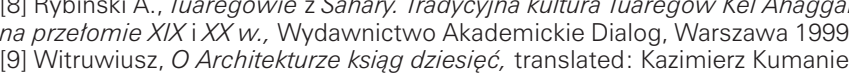
cki, Prószyńskii i Sp., 1999

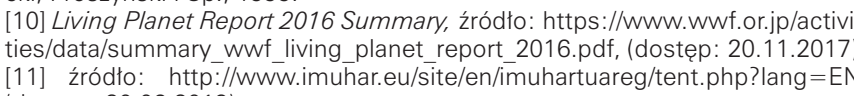

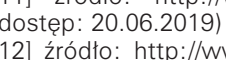
/Mww.inuvialuitsodhouse.ca/dwellings/warm-season/, (do[13] Żródto: http://mwww.parkassociati.com/EN/Projects/2011/the_cube_by electrolux =-milan_p p1422.aspx, (dostep: 20.06.2019) mal, (dostepp: 20.06.2019)

作 16] żródto: https://www.treehugger.com/modular-design/modular-plugin-to

wer-shenzen-peoples-architecture-office.html, (dostepp: 20.06.20
[17] zródto: htpp://www.urbanrigger.com, (dostẹp: 20.06.2019)

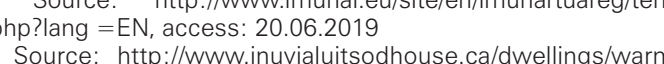
-season/, access: 20.06.2019 4 Taschen GMBH 2010, 176179
${ }^{9}$ Conrads U. Programs and manifestoes on $20^{\text {th }}$ century architecture, IIT Press 1977, , 99-100.
10 Busbea L., The Urban Utopia in France, 1960-1970, Massa chusetts Institute of Technology, 2007 .
11 Jencks CH., Kropt K., Teorie $i$ manifesty architektury wspó czesnej, Grupa Sztuka Architektury, Warszawa 2013, p. 258 .
${ }^{12}$ Koolhaas R., Obrist H.U., Project Japan. Metabolism Talks. Taschen 2011 .
13 Jodido P., Architecture Now! 4, Taschen GMBH 2010, 82-87. 14 Source: http://www.parkassociaticom/EN/Projects/2011
the cube_by_electrolux_-_milan_p1422.aspx, access (n)

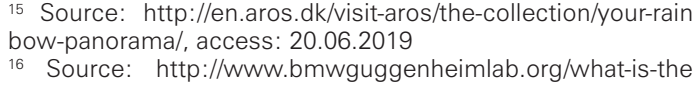
16 Source: http://Mww.bmwguggenheimlab.org/what-is-the
lab, access: 20.06.2019 17. Source: https://www.treehugger.com/modular-design/moaccess: 20.06 .2019
is Source: http://www.urbanrigger.com, access: 20.06.2019

\section{BIBLIOGRAPHY}

(1) Bẹben W. Aborygeni, pierwsi nomadzi. Życie i Kultura, Wy-

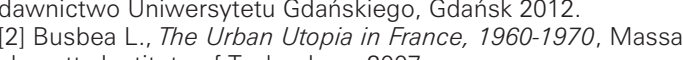
chusetts Institute of Technology, 2007.

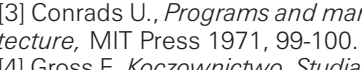

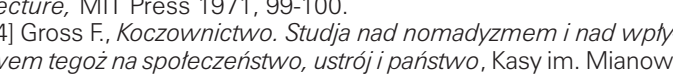

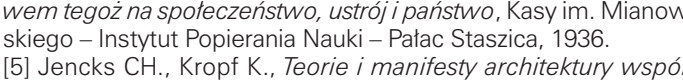
czesnej, Grupa Sztuka Architektury, Warszawa 2013 [7] Koolhaas R., Obrist H. U., Project Japan. Metabolism Talks.

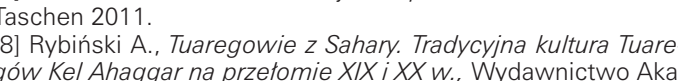
demickie Dialog, Warszawa 1999.

[9] Witruwiusz, OArchitekturze ksiag dziesięc, translated: Każ-

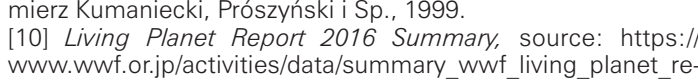

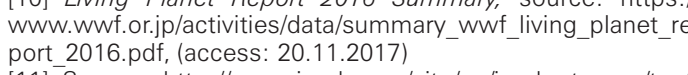

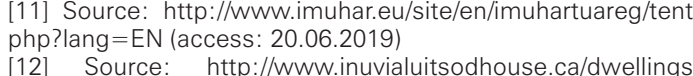
[12] Source: http:///Www.inuvialuitsodhouse. ca/dwellings/
warm-season/, (access: 20.06.2019)

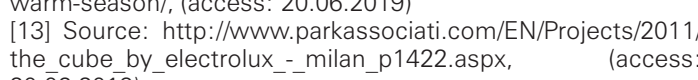
114] Source: http:///en.aros.dk/visit-aros/the-collection/your-rainbow-panorama/, (access: 20.06.2019)
[15] Source: http://www.bmwguggenheimlab.org/what-is-the

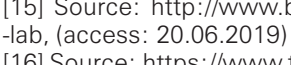
[16] Source: https: / /www.treehugger.com/modular-design/modular-plugin-tower-shenzen-peoples-architecture-office. htm
(access: 20.06.2019)
[17] Source: http://www.urbanrigger.com, (access: 20.06.2019) 